\title{
KAJIAN PERKATAAN BAHASA CINA BERKAITAN DENGAN PENDIDIKAN YANG DIGUNAKAN DI MALAYSIA BERDASARKAN KORPUS BERKOMPUTER
}

\section{A STUDY OF EDUCATION-RELATED CHINESE WORDS USED IN MALAYSIA-BASED COMPUTER CORPUS}

\section{Lau Su Kia* dan Su’ad Awab}

Fakulti Bahasa dan Linguistik, Universiti Malaya, Kuala Lumpur, MALAYSIA *Corresponding author: lausk@um.edu.my

Published online: 24 April 2019

To cite this article: Lau, S.K. and Su'ad Awab. 2019. Kajian perkataan bahasa Cina berkaitan dengan pendidikan yang digunakan di Malaysia berdasarkan korpus berkomputer. Kajian Malaysia 37(1): 83-107. https://doi.org/10.21315/km2019.37.1.4

To link to this article: https://doi.org/10.21315/km2019.37.1.4

\section{ABSTRAK}

Penyelidikan ini dijalankan untuk mengkaji perkataan-perkataan bahasa Cina berkaitan dengan pendidikan yang berciri tempatan berdasarkan data Korpus Pendidikan Malaysia (KPM) serta faktor-faktor kewujudannya. KPM menjadi korpus utama, manakala Korpus Pendidikan China (KPC) dijadikan sebagai korpus perbandingan, dan BLCU Chinese Corpus (BCC) dijadikan sebagai korpus rujukan. Data KPM terdiri daripada berita nasional dan artikel yang membincangkan isu-isu pendidikan tempatan dalam tiga jenis akhbar bahasa Cina di Malaysia, iaitu Sinchew Daily, Nanyang Siang Pau dan Guang Ming Daily dari Januari 2011 hingga Disember 2013. Data KPM yang diberi tag dimasukkan ke dalam perisian AntConc 3.2.4w untuk diproses. Perkataan-perkataan yang berkaitan dengan pendidikan diperoleh daripada senarai perkataan dalam perisian tersebut lalu dikenal pasti melalui kaedah menyemak Kamus Ensiklopedia Pendidikan dan juga merujuk kepada tujuh orang pakar. Seterusnya, perkataanperkataan tersebut dicari satu demi satu dalam KPC dan BCC. Terdapat sebanyak 69 perkataan berkaitan dengan pendidikan yang berciri tempatan digunakan dalam KPM sahaja. Hampir semua perkataan tersebut ialah kata nama. Hanya satu daripadanya merupakan kata kerja, iaitu 国小化 (menjadikan bercorak sekolah kebangsaan). Sebahagian besar daripada perkataan tersebut berkaitan dengan sekolah, orang yang terlibat dalam pendidikan, pengajaran dan pembelajaran. Konsep, polisi, sistem dan organisasi pendidikan di Malaysia yang berlainan 
dengan China turut menghasilkan kata-kata nama yang berciri tempatan. Kepelbagaian sekolah, kelas dan etnik di Malaysia juga melahirkan kata-kata nama berciri tempatan yang merujuk kepada sekolah, kelas dan pelajar. Selain daripada faktor sosial, peminjaman, penterjemahan daripada bahasa Melayu dan penyingkatan kata juga merupakan faktor-faktor kewujudan perkataan-perkataan yang berciri tempatan. Terdapat juga perkataan yang dicipta merujuk kepada perayaan yang berkaitan dengan pendidikan di Malaysia. Diharapkan agar dapatan kajian ini dapat dimasukkan ke dalam kamus bahasa Cina global pada masa hadapan untuk menjadikan kamus tersebut lebih terkini.

Kata kunci: perkataan, bahasa Cina, pendidikan, tempatan, korpus

\begin{abstract}
The purpose of this study is to identify local Chinese education-related words based on the Malaysian Education Corpus (KPM) and its resulting factors. KPM is the main corpus, while the China Education Corpus (KPC) is a comparable corpus and BLCU Chinese Corpus (BCC) is a reference corpus. KPM data include national news and articles related to the issue of education in three types of Chinese newspapers in Malaysia from January 2011 to December 2013, namely Sinchew Daily, Nanyang Siang Pau and Guang Ming Daily. After KPM was tagged, it was then run through AntConc 3.2.4w software to be processed. Education-related words obtained from a wordlist were then identified and validated by checking against a dictionary for education encyclopedia and then referred to seven experts. These words were then searched in the KPC and BCC. A total of 69 local education words which are only used in the KPMwere detected. Almost all of these words are nouns, and only one word is a verb, namely 国小化 (make it like national schools). Most of the local words are related to schools, people involved in education as well as teaching and learning. The differences in concept, policy, system and organisation of education between Malaysia and China have generated local nouns. Diversity of school, class and ethnicity in Malaysia have also produced various types of nouns that refer to local schools, classrooms as well as students. In addition to social factors, borrowing, translation from the Malay language and abbreviation are also factors resulting in the existence of local words. There is also a coined noun which refers to festivals related to education in Malaysia. It is hoped that the findings will be incorporated into global Chinese dictionaries in the future to make the dictionaries more current.
\end{abstract}

Keywords: word, Chinese, education, local, corpus 


\section{PENGENALAN}

Sejak kebelakangan ini, lebih banyak korpus telah dibangunkan di Malaysia untuk memudahkan penyelidikan mengenai deskripsi, terjemahan dan kajian yang berkaitan dengan genre, antaranya termasuk projek korpus yang melibatkan analisis teks-teks bertulis dalam beberapa genre utama, terutamanya akhbar, majalah dan buku (Siti Aeisha dan Hajar 2014). Setiap genre mempunyai perkataan yang tersendiri (Anderson 2006). Terdapat pelbagai jenis perkataan yang berkaitan dengan pendidikan digunakan dalam wacana pendidikan, seperti berita dalam negara, artikel dan laporan yang membincangkan isu-isu pendidikan. Kajian ini memberi fokus kepada perkataan bahasa Cina (BC) yang berkaitan dengan pendidikan.

Pelbagai jenis isu pendidikan telah dibincangkan dalam media massa bercetak BC di Malaysia sejak 10 tahun kebelakangan ini, khususnya berkaitan dengan isu-isu pendidikan $\mathrm{BC}$ tempatan. Hal ini turut menunjukkan bahawa pendidikan merupakan isu penting yang amat diambil berat oleh anggota masyarakat serta dibincangkan dari masa ke semasa.

Bahasa merupakan sejenis fenomena masyarakat, iaitu perubahan sesuatu bahasa berkait rapat dengan masyarakat pengguna bahasa tersebut (Chen 1999). Penggunaan perkataan-perkataan berkaitan dengan pendidikan dalam akhbar di Malaysia bukan sahaja membayangkan sistem pendidikan tempatan, malahan dapat memberi gambaran tentang keadaan pendidikan di Malaysia.

Disebabkan kajian leksikologi ini dijalankan berdasarkan data korpus berkomputer, maka korpus perlu dibentuk untuk mencapai objektif penyelidikan ini. Korpus merupakan koleksi teks sampel sama ada dalam bahasa bertulis atau lisan, dalam bentuk yang boleh dibaca oleh mesin dan boleh dianotasi dengan pelbagai bentuk linguistik (McEnery, Xiao dan Tono 2006). Korpus Pendidikan Malaysia (KPM) merupakan korpus utama dalam penyelidikan ini, manakala Korpus Pendidikan China (KPC) dan BLCU Chinese Corpus (BCC) dibandingkan dengan KPM untuk mengenal pasti perkataan-perkataan BC berkaitan dengan pendidikan yang berciri tempatan. Perkataan-perkataan tersebut hanya digunakan dalam kalangan pengguna BC Malaysia, iaitu BC Malaysia dianggap sebagai bahasa yang "telah keluar dari kawasan China" (Li 1998).

Walaupun BC Malaysia berasal dari Putonghua di China (bahasa induk), tetapi disebabkan bahasa ini telah dipisahkan daripada bahasa induk dalam tempoh masa yang panjang, maka $\mathrm{BC}$ Malaysia mempunyai sedikit perbezaan dengan Putonghua. Tambahan pula, faktor geografi dan sosiobudaya tempatan juga mengakibatkan BC Malaysia membawa ciri tempatan. Ciri tersebut dibayangkan melalui penghasilan dan penggunaan item-item leksikal berciri tempatan yang berlainan dengan Putonghua dalam kalangan pengguna BC di Malaysia. Sistem sebutan dan nahu BC Malaysia adalah hampir sama dengan Putonghua, namun 
terdapat sedikit perbezaan dari segi perbendaharaan kata antara BC tempatan dengan Putonghua (Huang 2014). Sesetengah perkataan tersebut bukan sahaja mempunyai ciri etnik, zaman, kepelbagaian dan kesubjektifan yang ketara, tetapi juga membayangkan masyarakat dan sosiobudaya tempatan (Li 1998).

Terdapat pelbagai jenis perkataan berkaitan dengan pendidikan yang berciri tempatan hanya digunakan di Malaysia (dalam KPM), sebaliknya tidak digunakan di China (dalam KPC dan BCC). Terdapat juga perkataan yang digunakan dalam ketiga-tiga korpus, tetapi yang digunakan dalam korpus perbandingan merujuk kepada sesuatu yang terdapat di Malaysia, sebaliknya tidak terdapat di China. Perkataan-perkataan tersebut bukan sahaja menonjolkan ciri istimewa BC Malaysia yang berlainan dengan BC China, malahan membayangkan kepelbagaian sekolah, pelajar dan persatuan pendidikan di Malaysia.

\section{PERNYATAAN MASALAH}

Kajian-kajian lepas yang meneliti perkataan-perkataan BC yang digunakan dalam bidang sukan, hiburan, ekonomi dan pengiklanan di Malaysia telah dijalankan oleh penyelidik-penyelidik tempatan, iaitu Seng (2006), Chong (2007), Tan (2008), Loh (2009), dan Lau (2010). Namun, setakat ini kajian yang khususnya dijalankan untuk meneliti perkataan-perkataan bidang pendidikan yang berciri tempatan di Malaysia masih belum ditemui sedangkan pendidikan merupakan salah satu isu penting yang dibincangkan dari masa ke semasa. Justeru, perkara tersebut dianggap sebagai salah satu kelompangan yang perlu diisi oleh kajian ini.

Tambahan pula, sebahagian besar daripada perkataan berkaitan dengan pendidikan yang kerap digunakan di Malaysia masih belum dimasukkan ke dalam kamus BC seperti Kamus BC Moden dan Kamus BC Global Abad Baru. Sebagai contoh, makna 淡 ialah tawar, manakala makna 小 ialah kecil. Dalam BC di Malaysia, 淡小 merujuk kepada sekolah jenis kebangsaan (Tamil) (SJK(T)), tetapi bukan "tawar" dan "kecil". Oleh sebab perkataan tersebut belum dikamuskan, maka hal ini mungkin mengakibatkan pembaca luar negara menyalahtafsirkan makna perkataan tersebut sebagai "tawar" dan "kecil" atau tidak memahami makna kata nama tersebut dalam konteks ayat yang digunakan. Fenomena ini dikesan dalam kajian rintis. Masalah tersebut turut mengakibatkan mesej penulis tidak dapat disampaikan secara tepat kepada pembaca. Justeru, kajian leksis seperti ini wajar dijalankan untuk menyenaraikan perkataan berkaitan dengan pendidikan yang digunakan di Malaysia. 


\section{OBJEKTIF DAN PERSOALAN KAJIAN}

Kajian leksis ini dijalankan untuk membandingkan data KPM dengan KPC dan BCC. Tujuan spesifiknya adalah untuk mengkaji perkataan-perkataan BC berkaitan dengan pendidikan yang berciri tempatan berdasarkan data KPM. Soalan-soalan berikut perlu dijawab:

1. Apakah perkataan-perkataan berkaitan dengan pendidikan yang berciri tempatan yang digunakan di Malaysia (dalam KPM)?

2. Apakah kategori dan kelas kata perkataan-perkataan yang berciri tempatan tersebut?

3. Apakah ciri-ciri linguistik perkataan-perkataan yang berciri tempatan tersebut?

4. Mengapakah perkataan-perkataan yang berciri tempatan tersebut hanya digunakan di Malaysia (dalam KPM), sebaliknya tidak digunakan di China (dalam KPC dan BCC)?

\section{TINJAUAN LITERATUR}

Evolusi bahasa boleh dilihat dari segi fonologi, item leksikal, tatabahasa, dialek, semantik, laras bahasa dan sebagainya (Labov 2001). Evolusi dari segi item leksikal turut melahirkan perkataan-perkataan berciri tempatan (Cao 2010). Perkataan-perkataan tersebut dihasilkan secara semula jadi dan diterima oleh pengguna bahasa dalam sesuatu masyarakat. Perkataan tersebut tidak digunakan secara umum di seluruh dunia, sebaliknya dipakai dalam kalangan masyarakat atau di negara tertentu sahaja. Tambahan pula, perkataan yang berciri tempatan mempunyai ciri-ciri budaya tempatan yang ketara serta membayangkan ciri-ciri istimewa dan fenomena masyarakat yang menggunakannya (Shi, Shao dan Zhu 2006).

Tambahan pula, sebuah buku yang mengumpulkan lebih kurang 700 perkataan baru BC yang diwujudkan di China dari tahun 2003 hingga 2005 telah dihasilkan oleh Song dan Yang (2006). Perkataan-perkataan tersebut diperoleh daripada akhbar BC di China, iaitu RenminRibao, Guangzhou Ribao, Jing Hua Shibao, Zhongguo Qingnian Bao dan Xin Jing Bao. Sebahagian kecil daripadanya merupakan perkataan yang berkaitan dengan pendidikan. Antaranya termasuk 课改 (pembaharuan kurikulum sekolah), 精致教育 (konsep pendidikan yang sangat teliti dan terperinci), 借分制 (sistem peminjaman markah) dan 示范高 中 (sekolah tinggi contoh). Perkataan-perkataan tersebut hanya digunakan di tanah besar China, sebaliknya belum digunakan di negara-negara lain, antaranya termasuk Malaysia. 
Perkataan-perkataan BC berciri tempatan yang wujud dalam akhbar BC di Malaysia pernah diselidik oleh Chong (2007). Data kajiannya diambil daripada surat khabar BC di Malaysia, iaitu Sinchew Daily dan China Press pada bulan Mac 2005. Hasil dapatan kajiannya menunjukkan bahawa terdapat sebilangan kecil item leksikal yang berkaitan dengan pendidikan digunakan dalam kedua-dua akhbar BC di Malaysia. Antaranya termasuk 国小 (sekolah kebangsaan (SK)), 独中 (sekolah menengah persendirian Cina), 半日制 (sistem persekolahan separuh hari), 固打 制 (sistem kuota), 教专 (kesatuan perkhidmatan perguruan kebangsaan, NUTP), 家协 (Persatuan Ibu Bapa dan Guru, PIBG), 学院大学 (universiti kolej), 华教卡 (kad pendidikan BC), dan 学生警察 (kadet polis). Sebanyak 64 item leksikal yang berkaitan dengan pendidikan telah dikesan olehnya. Dapatan tersebut mempunyai bilangan yang paling banyak jika dibandingkan dengan item-item leksikal lain.

Faktor-faktor yang mengakibatkan perubahan bahasa terbahagi kepada faktor dalaman dan faktor luaran. Faktor dalaman biasanya dikaitkan dengan ciriciri struktur bahasa sama ada dalam fonologi dan morfosintaksis atau kontingensi penghasilan bahasa dalam fonetik. Faktor luaran pula merupakan faktor sosial yang berkaitan dengan masyarakat yang terdiri daripada pengguna bahasa (Hickey 2012).

Aitchison (2001) menunjukkan bahawa faktor-faktor yang mengakibatkan evolusi bahasa adalah rumit dan berdasarkan "prasyarat" linguistik dalaman dan luaran. Beliau mengemukakan tiga faktor sosiolinguistik yang mengakibatkan perubahan bahasa, iaitu (1) fesyen, (2) pengaruh asing, dan (3) keperluan sosial. Pertama, faktor fesyen dan pengaruh sosial perlu diambil kira kerana bahasa yang digunakan oleh pengguna bahasa boleh berubah mengikut arah fesyen secara beransur-ansur selama bertahun-tahun, tetapi faktor tersebut bukan faktor utama. Dari segi faktor pengaruh asing, evolusi bahasa berlaku akibat peminjaman bahasa (Aitchison 2001). Menurut Trask (1994), pengguna sesuatu bahasa akan berhubung dengan pengguna bahasa yang menggunakan bahasa lain. Hubungan ini turut mengakibatkan berlakunya peminjaman perkataan daripada bahasa lain. Peminjaman juga berlaku dalam sebutan dan tatabahasa. Satu lagi faktor sosiolinguistik yang menyebabkan evolusi bahasa adalah keperluan sosial yang terutamanya berlaku pada tahap perbendaharaan kata. Evolusi bahasa berlaku melalui cara mencipta perkataan baharu kerana perkataan tersebut diperlukan oleh sesebuah masyarakat untuk merujuk kepada sesuatu benda. Perkara tersebut berlaku apabila perkataan lama kehilangan fungsi dan kesannya (Aitchison 2001).

Evolusi dan variasi bahasa turut menghasilkan perkataan-perkataan berciri tempatan yang berlainan dengan bahasa induk. Kewujudan perkataan-perkataan tersebut adalah disebabkan oleh faktor bahasa, sosial dan psikologi pengguna bahasa (Wang 2002; Huang 2014). BC Malaysia lebih kurang sama dengan BC Singapura. Wang (2002) menunjukkan bahawa terdapat tujuh faktor bahasa 
(dalaman) dan sosial (luaran) yang mengakibatkan kewujudan item-item leksikal berciri tempatan dalam BC Singapura, iaitu:

1. Pengaruh bahasa lain

Pengaruh bahasa lain turut mengakibatkan sebilangan perkataan bahasa Melayu (BM) dan bahasa Inggeris (BI) dipinjam ke dalam BC Singapura. Banyak benda dan perkara baharu dinamakan dalam BI terlebih dahulu, dan kemudiannya diterjemahkan ke dalam BC. Misalnya, item leksikal BC 经典汽车 (kereta klasik) diterjemahkan daripada frasa BI, iaitu classic car. Selain itu, perkataan-perkataan dalam BC Singapura seperti 必甲 (pickup) dan 积宝 (jack pot) dipinjam daripada BI. Sebilangan kecil lagi perkataan $\mathrm{BC}$ dipinjam daripada BM, misalnya 峇拉煎 (belacan) dan 奎笼 (kelong).

2. Pengaruh dialek Cina

Pengaruh dialek Cina terhadap BC turut menghasilkan item-item leksikal yang membawa makna berciri tempatan dalam BC Singapura. Misalnya, 惊输 (kiasu) yang kerap digunakan dalam kalangan pengguna-pengguna $\mathrm{BC}$ di Singapura ialah perkataan $\mathrm{BC}$ yang dihasilkan akibat pengaruh dialek Hokkien.

3. Latar belakang pendidikan dwibahasa

Sistem pendidikan dwibahasa di Singapura bukan sahaja menjadikan BI sebagai bahasa pengantar dalam proses pengajaran dan pembelajaran, tetapi juga menjadikan $\mathrm{BC}$ sebagai mata pelajaran yang wajib dipelajari. Perkara ini membolehkan pengguna BC di Singapura menguasai dua jenis bahasa tersebut. Fenomena tersebut turut menghasilkan kata berhuruf berciri tempatan yang memperlihatkan kombinasi $\mathrm{BC}$ dan $\mathrm{BI}$, misalnya $U$ 转 (pusingan $\mathrm{U}$ ).

4. Keadaan masyarakat

Masyarakat di Singapura terdiri daripada berbilang kaum, bahasa dan budaya. Pelbagai bahasa digunakan dalam masyarakat tersebut, dan bahasa-bahasa yang berlainan saling mempengaruhi dan berintegrasi, misalnya sebilangan kecil perkataan $\mathrm{BC}$ yang berciri tempatan memperlihatkan pengaruh BM.

5. Merujuk kepada sesuatu yang tertentu

Perkataan berciri tempatan dihasilkan untuk merujuk kepada sesuatu yang hanya terdapat di sesebuah kawasan atau negara tertentu. Misalnya, kata nama 拥车证 (sijil pemilikan kenderaan, COE) hanya digunakan di Singapura. 
6. Perubahan di China

Perubahan sistem yang berlaku di tanah besar China turut mengakibatkan sebilangan kecil perkataan $\mathrm{BC}$ yang digunakan sebelum ini tidak digunakan lagi. Oleh sebab China ialah sebuah negara komunis, maka perkataanperkataan lama yang mempunyai unsur kehinaan seperti 邮差 (posmen) sudah tidak digunakan dalam masyarakat moden China kini. Perkataanperkataan tersebut ditukar ganti dengan perkataan lain yang tidak mempunyai unsur kehinaan, iaitu 邮递员 (posmen). Akan tetapi, perkataan-perkataan lama yang pernah digunakan dalam BC tanah besar China sebelum ini masih digunakan dalam BC Singapura, dan ia turut menjadi perkataan yang berciri tempatan.

7. Mengelak pertindihan

Pengguna BC di Singapura dan Malaysia cuba mengelak daripada menggunakan item leksikal yang terdiri daripada morfem 汉 (Han, iaitu Cina) dan 中 (China) supaya tidak mewujudkan pertindihan dengan BC tanah besar China, sebaliknya morfem 华 (Cina) digunakan. Hal ini dibayangkan dalam penggunaan item leksikal yang didepankan oleh morfem 华 (Cina) dalam BC Singapura dan Malaysia, misalnya 华乐 (muzik rakyat Cina).

Selain daripada faktor-faktor yang dikemukakan oleh Wang (2002), faktor yang diakibatkan oleh pengguna bahasa juga mengakibatkan kewujudan item-item leksikal BC berciri tempatan di Malaysia (Huang 2014), iaitu:

1. Berkepentingan sesuatu yang baru

Oleh sebab pengguna BC Malaysia berasa sesetengah item leksikal BC yang sedia ada tidak mencukupi untuk tujuan komunikasi, maka mereka mencipta item-item leksikal baharu yang berciri tempatan untuk mengisi "kekosongan" tersebut di samping memenuhi keperluan dalam kehidupan masyarakat.

2. Kepantasan dan keringkasan

Untuk menyampaikan maklumat dan informasi dengan cara pantas dan berkesan, pelbagai item leksikal yang ringkas dan pendek turut dihasilkan lalu digunakan dalam BC Malaysia, misalnya 多多博彩 (Sports Toto) disingkatkan menjadi 多多 (Toto).

Faktor-faktor yang dibincangkan di atas turut dirujuk dalam proses menganalisis faktor-faktor kewujudan perkataan-perkataan berkaitan dengan pendidikan yang berciri tempatan di Malaysia (dalam KPM). 


\section{METODOLOGI KAJIAN}

Kajian leksis ini dijalankan berdasarkan data korpus berkomputer. Justeru, sumber teks korpus ditentukan terlebih dahulu. Seterusnya, korpus utama dan korpus perbandingan dibentuk, dan korpus rujukan ditentukan. Kaedah mengenal pasti dan menganalisis perkataan-perkataan yang berkaitan dengan pendidikan berdasarkan data korpus juga dibincangkan seperti berikut. Kedua-dua kaedah kuantitatif dan kualitatif digunakan dalam penyelidikan ini.

\section{Sumber Teks Korpus}

Data korpus kajian ini adalah jenis monolingual, iaitu dalam BC sahaja. Data akhbar dipilih kerana akhbar melaporkan peristiwa-peristiwa penting melalui penggunaan bahasa (Hishamudin dan Norsimah 2011). Data korpus penyelidikan ini dipungut daripada tiga jenis surat khabar BC dalam talian di Malaysia, iaitu: (1) Sinchew Daily, (2) Nanyang Siang Pau, dan (3) Guang Ming Daily dari Januari 2011 hingga Disember 2013. Ketiga-tiga surat khabar BC tersebut mempunyai golongan pembaca tempatan yang ramai. Teks-teks yang dikumpul untuk membentuk KPM terdiri daripada:

1. Berita nasional yang berkenaan dengan isu-isu pendidikan di Malaysia;

2. Artikel dalam halaman pengemukaan pendapat yang mengulas dan membincangkan isu-isu pendidikan di Malaysia;

3. Artikel dan laporan tentang isu-isu pendidikan di Malaysia dalam halaman tambahan surat khabar.

Teks-teks yang dijadikan sebagai data KPM ini membincangkan isu-isu pendidikan $\mathrm{BC}$ tempatan, masalah guru sandaran, masalah yang dihadapi oleh sekolah jenis kebangsaan Cina ( $\mathrm{SJK}(\mathrm{C})$ ) dan sekolah menengah persendirian Cina (SMPC), polisi pendidikan, bahasa pengajaran dan pembelajaran (P\&P) mata pelajaran Matematik dan Sains, pengiktirafan sijil peperiksaan bersepadu (UEC), masalah tentang guru besar di SJK(C) yang tidak fasih $\mathrm{BC}$, kelas bahasa ibunda (POL) di sekolah menengah kebangsaan (SMK), pelan pembangunan pendidikan Malaysia, kerjasama antara universiti-universiti tempatan dengan luar negara, rancangan projek pendidikan, masalah disiplin pelajar dan sebagainya. Teks-teks tersebut disemak sebanyak dua kali untuk memastikan ia tidak bertindih.

Teks-teks KPC yang berkenaan dengan pendidikan pula dikumpul daripada akhbar-akhbar BC di China dalam talian dari Januari 2011 hingga Disember 2013. Akhbar-akhbar tersebut termasuk Renmin Ribao, Beijing Ribao, Wenhui Bao, Jinghua Shibao, Zhongguo Qingnian Bao, dan Zhongguo Jiaoyu Bao. 


\section{Saiz Korpus}

Satu korpus utama dibentuk untuk tujuan penyelidikan ini, manakala dua korpus lain dijadikan sebagai korpus perbandingan dan korpus rujukan.

\section{Korpus Utama}

Korpus utama kajian ini ialah KPM. KPM terdiri daripada 3,286 buah teks yang berkaitan dengan pendidikan di Malaysia dari tahun 2011 hingga 2013. Korpus tersebut mempunyai 2,691,235 aksara (lihat Jadual 1).

Jadual 1: Bilangan teks dan aksara dalam KPM

\begin{tabular}{cccccc}
\hline \multirow{2}{*}{ Tahun } & \multicolumn{3}{c}{ Akhbar } & $\begin{array}{c}\text { Bilangan } \\
\text { teks }\end{array}$ & $\begin{array}{c}\text { Bilangan } \\
\text { aksara }\end{array}$ \\
\cline { 2 - 4 } & Sinchew Daily & Nanyang Siang Pau & Guang Ming Daily & 1,096 & 903,077 \\
\hline 2011 & 365 & 367 & 364 & 1,095 & 891,601 \\
2012 & 366 & 364 & 365 & 1,098 & 896,557 \\
2013 & 369 & 367 & 362 & 3,289 & $2,691,235$ \\
\hline \multicolumn{5}{c}{ Jumlah keseluruhan: } \\
\hline
\end{tabular}

\section{Korpus Perbandingan dan Korpus Rujukan}

Untuk membuat perbandingan dengan KPM bagi mengkaji perkataan-perkataan yang berkaitan dengan pendidikan yang berciri tempatan, KPC dijadikan sebagai korpus perbandingan, manakala BCC yang lebih besar dijadikan sebagai korpus rujukan.

\section{KPC}

Satu korpus perbandingan yang terdiri daripada teks-teks tentang pendidikan dalam akhbar BC di China telah dibentuk, iaitu KPC. KPC juga terdiri daripada lebih kurang 2.6 juta aksara. Saiz dan bilangan aksaranya lebih kurang sama dengan KPM (lihat Jadual 2).

Jadual 2: Bilangan teks dan aksara dalam KPC

\begin{tabular}{ccc}
\hline Tahun & Bilangan teks & Bilangan aksara \\
\hline 2011 & 1,146 & 874,571 \\
2012 & 1,139 & 893,168 \\
2013 & 1,153 & 886,520 \\
\hline Jumlah keseluruhan: & 3,438 & $2,654,259$ \\
\hline
\end{tabular}


Dari segi saiz, KPC terdiri daripada 3,438 buah teks berkaitan dengan pendidikan yang diterbitkan dalam akhbar-akhbar BC di China dari tahun 2011 hingga 2013.

\section{$B C C$}

Korpus rujukan digunakan untuk membuat perbandingan standard dalam bahasa yang sama atau dengan bahasa lain. Biasanya, korpus yang saiznya sangat besar dijadikan sebagai korpus rujukan kerana ia merangkumi bidang bahasa yang luas serta terdiri daripada pelbagai jenis bahan yang diperoleh daripada sumber yang berlainan (Leech 2002). Satu lagi korpus yang lebih besar, iaitu BCC dijadikan sebagai korpus rujukan dalam kajian ini. Korpus ini boleh diakses dalam talian. ${ }^{1}$ BCC dibentuk oleh Beijing Language and Culture University. Korpus ini terdiri daripada lebih kurang 15 billion aksara. Teks BC moden di dalamnya diperoleh daripada pelbagai sumber yang merangkumi pelbagai bidang. Antaranya termasuk teks-teks berkaitan dengan pendidikan di China yang diterbitkan dalam akhbarakhbar di China seperti Renmin Ribao, Beijing Ribao, Fujian Ribao, dan Xiamen Ribao.

\section{Kaedah Pengenalpastian}

Pada peringkat awal, semua perkataan dalam KPM yang dianggap sebagai perkataan yang berkaitan dengan pendidikan diperoleh daripada senarai perkataan dalam perisian AntConc 3.2.4w lalu disenaraikan. Seterusnya, 教育百科辞 典 (Kamus Ensiklopedia Pendidikan) disemak untuk mengenal pasti perkataanperkataan yang disenaraikan tersebut merupakan perkataan yang berkaitan dengan pendidikan. Sebagai contoh, 教学 (P\&P) dan 教师 (guru) dianggap sebagai perkataan yang berkaitan dengan pendidikan pada mulanya. Selepas Kamus Ensiklopedia Pendidikan disemak, didapati bahawa kedua-dua perkataan tersebut telah dikamuskan, dan ia dikenal pasti sebagai perkataan yang berkaitan dengan pendidikan. Yang ingin ditekankan di sini ialah semua kata nama khas yang merujuk kepada sekolah, kolej, universiti, organisasi pendidikan dan pendidik tidak dijadikan sebagai perkataan yang berkaitan dengan pendidikan dalam penyelidikan ini.

Bagi perkataan yang belum dikamuskan tetapi dianggap sebagai perkataan pendidikan pula, tujuh orang pakar termasuk profesor pakar leksikologi $\mathrm{BC}$, penyunting kamus $\mathrm{BC}$, dan juga pensyarah kanan fakulti pendidikan universiti tempatan telah dirujuk untuk memastikan bahawa perkataan tersebut sememangnya perkataan yang berkaitan dengan pendidikan atau sebaliknya. Misalnya, 华教 (pendidikan BC) dan 淡小 ( $\mathrm{SJK}(\mathrm{T})$ ) masih belum dikamuskan dalam Kamus Ensiklopedia Pendidikan, tetapi kata-kata nama tersebut dianggap 
sebagai perkataan yang berkaitan dengan pendidikan oleh pakar-pakar tersebut. Oleh yang demikian, kedua-dua kata nama tersebut juga dikategorikan sebagai perkataan yang diselidik.

\section{Temu Bual dan Informan}

Setakat menyelidik perkataan-perkataan berkaitan dengan pendidikan yang berciri tempatan dari segi kategori, kelas kata, dan ciri linguistik tidak mencukupi. Penyelidikan ini didalami lagi untuk mengkaji faktor-faktor yang melahirkan perkataan-perkataan berciri tempatan tersebut.

Tiga orang informan tempatan dan tiga orang informan dari China ditemu bual untuk mengenal pasti faktor-faktor yang mengakibatkan sesetengah perkataan yang berkaitan dengan pendidikan hanya dipakai di Malaysia (KPM), tetapi tidak digunakan di China (KPC dan BCC). Selain itu, melalui informaninforman dari China, pengkaji juga dapat mengenal pasti sama ada sesuatu yang berkenaan dengan pendidikan yang terdapat di Malaysia juga terdapat di China atau sebaliknya.

Soalan-soalan temu bual berbentuk separa berstruktur dan dibentuk berdasarkan hasil analisis data korpus. Temu bual dijalankan secara bersemuka atau melalui telefon. Selepas maklum balas informan-informan tersebut dikemaskini, respons tersebut ditunjukkan sekali lagi kepada informan-informan tersebut untuk diperakui. Tujuannya adalah untuk memastikan data kajian ini boleh dipercayai dan sah.

\section{Kaedah Penganalisisan}

Semua perkataan yang digunakan dalam KPM dipaparkan dalam senarai perkataan (wordlist) perisian AntConc 3.2.4w. Seterusnya, perkataan-perkataan berkaitan dengan pendidikan yang wujud dalam KPM dikenal pasti lalu diekstrak daripada senarai perkataan perisian tersebut. Sebanyak 593 perkataan BC yang berkaitan dengan pendidikan telah dikesan dalam KPM.

Seterusnya, 593 perkataan tersebut dicari dalam KPC dan kemudiannya dicari sekali lagi dalam korpus rujukan yang lebih besar, iaitu BCC. Bagi perkataanperkataan yang tidak digunakan dalam kedua-dua korpus tersebut, ia dianggap sebagai perkataan yang berciri tempatan.

Perkataan-perkataan tersebut digolongkan kepada lapan kategori dalam bentuk jadual lalu dianalisis dengan kaedah kuantitatif. Kelas-kelas katanya juga ditentukan dengan merujuk kepada Kamus BC Moden serta berdasarkan fungsinya dalam teks. Seterusnya, perkataan-perkataan tersebut dibincangkan berserta 
contoh-contoh ayat KPM yang tabii. Selepas maklum balas informan dikemaskini, kaedah kualitatif digunakan untuk membincangkan faktor-faktor dari segi bahasa dan sosial yang menghasilkan perkataan-perkataan berciri tempatan tersebut.

\section{PERKATAAN BERKAITAN DENGAN PENDIDIKAN YANG HANYA DIGUNAKAN DALAM KPM (MALAYSIA)}

Daripada 593 perkataan $\mathrm{BC}$ berkaitan dengan pendidikan yang telah dikesan dalam KPM, hanya 69 perkataan (11.64\%) yang digunakan dalam KPM, seperti dalam Jadual 3. Dengan kata lain, perkataan-perkataan tersebut hanya digunakan di Malaysia.

Jadual 3: Kategori perkataan berkaitan dengan pendidikan yang berciri tempatan

\begin{tabular}{|c|c|c|}
\hline Kategori & Bilangan perkataan & Jumlah (\%) \\
\hline Jenis pendidikan & 1 & $1(1.45 \%)$ \\
\hline Sekolah dan institusi pengajian & & $20(28.99 \%)$ \\
\hline Sekolah & 19 & \\
\hline Institusi pendidikan tinggi & 1 & \\
\hline Orang yang terlibat dalam pendidikan & & $22(31.88 \%)$ \\
\hline Pelajar & 20 & \\
\hline Guru dan profesor & 2 & \\
\hline \multicolumn{3}{|l|}{ Pengajaran dan pembelajaran (P\&P) } \\
\hline Aktiviti pengajaran & 1 & \\
\hline Aktiviti pembelajaran & 1 & $12(17.39 \%)$ \\
\hline Pentaksiran & 1 & \\
\hline Kelas & 6 & \\
\hline Perguruan & 3 & \\
\hline Pentadbiran & 1 & $1(1.45 \%)$ \\
\hline Sistem & 2 & $2(2.90 \%)$ \\
\hline \multicolumn{3}{|l|}{ Persatuan pendidikan } \\
\hline Peringkat kebangsaan dan negeri & 5 & $8(11.59 \%)$ \\
\hline Peringkat sekolah & 3 & \\
\hline \multicolumn{3}{|l|}{ Lain-lain } \\
\hline Pengangkutan & 1 & $3(4.35 \%)$ \\
\hline Majlis dan hari peringatan & 2 & \\
\hline Jumlah keseluruhan & & $69(100 \%)$ \\
\hline
\end{tabular}


Berdasarkan Jadual 3, perkataan-perkataan berkaitan dengan pendidikan yang berciri tempatan terbahagi kepada lapan kategori. Lebih daripada separuh, iaitu 42 perkataan $(60.87 \%)$ tersebut merujuk kepada sekolah, IPT dan orang yang terlibat dalam bidang pendidikan. Bilangan perkataan dalam kedua-dua kategori tersebut hampir sama. Selain itu, sebanyak 12 perkataan (17.39\%) adalah berkaitan dengan pengajaran dan pembelajaran. Kategori ini terdiri daripada lima subkategori. Lapan lagi perkataan merujuk kepada persatuan pendidikan tempatan. Sebaliknya, hanya tujuh item leksikal (10.14\%) berciri tempatan digunakan dalam KPM untuk merujuk kepada pendidikan BC, sistem pendidikan, bahagian kementerian pendidikan, alat pengangkutan, majlis dan hari peringatan yang berkaitan dengan pendidikan. Hampir semua, iaitu 68 perkataan tersebut merupakan kata nama, manakala hanya satu perkataan merupakan kata kerja, iaitu 国小化 (menjadikan bercorak SK). Sebaliknya, tiada sebarang kata adjektif berciri tempatan dikesan.

Isu pendidikan BC kerap dibincangkan dalam akhbar BC tempatan. Hal ini turut menjadikan frekuensi 华教 (pendidikan BC) dalam KPM agak tinggi, iaitu sebanyak 3,242 kali. Pendidikan BC merupakan salah satu aliran pendidikan yang dipentingkan di SJK(C), SMJK(C) dan SMPC di Malaysia.

Jadual 4: Jenis pendidikan di Malaysia

\begin{tabular}{ccccc}
\hline Item & Perkataan & Terjemahan $(\mathrm{BM})$ & Kelas kata & Frekuensi (kali) \\
\hline 1. & 华教 & Pendidikan BC & KN & 3,242 \\
\hline
\end{tabular}

Berdasarkan Jadual 4, kata nama 华教 (pendidikan BC) dalam Item (1) adalah disingkatkan daripada 华文教育 atau 华语教育 (pendidikan BC) (Li 2010, 376). Menurut informan China, kata nama 华文 (BC) sangat jarang digunakan di China, dan 华文 (BC) jarang berkolokasi dengan 教育 (pendidikan) dalam BC China. Sebaliknya, perkataan 中文 (BC) lebih kerap digunakan dalam BC di China. Selain itu, BC dijadikan sebagai satu-satunya bahasa yang digunakan dalam P\&P di China. Hal ini turut mengakibatkan tiada perkataan yang khasnya digunakan untuk merujuk kepada pendidikan $\mathrm{BC}$ di negara tersebut.

Sistem pendidikan Malaysia yang mempunyai sekolah pelbagai aliran dan pengajaran dalam bahasa ibunda masing-masing turut menghasilkan pelbagai jenis sekolah. Sistemnya adalah berlainan dengan China. Terdapat sebanyak 19 kata nama yang merujuk kepada sekolah tempatan, seperti dalam Jadual 5 dan 6.

Di Malaysia, terdapat sekolah rendah dan menengah yang mementingkan pendidikan BC. Hal ini turut mewujudkan sekolah-sekolah yang menjadikan BC sebagai bahasa pengantar dalam P\&P, iaitu 华小 (disingkatkan daripada 华文 小学) dalam Item (2) yang merujuk kepada $\operatorname{SJK}(C)$. Berdasarkan Jadual 5, satu lagi kata nama sekolah, iaitu 独中 (SMPC) dalam Item (3) hanya terdapat dalam KPM. Kata nama tersebut dipendekkan daripada 华文独立中学 (SMPC). Oleh 
sebab isu-isu tentang SJK(C) dan SMPC banyak dibincangkan dalam teks akhbar BC di Malaysia, hal ini turut mengakibatkan frekuensi 华小 $(\mathrm{SJK}(\mathrm{C}))$ dan 独中 (SMPC) menjadi tinggi dalam KPM, seperti dalam Jadual 5. Menurut informan China, oleh sebab BC secara umumnya dijadikan sebagai bahasa pengantar P\&P di sekolah-sekolah China, maka tiada kata nama seperti 华小 (SJK(C)) yang khasnya digunakan dalam KPC dan BCC untuk merujuk kepada sekolah-sekolah jenis ini di China.

Jadual 5: Sekolah-sekolah di Malaysia

\begin{tabular}{cllcc}
\hline Item & Perkataan & Terjemahan (BM) & $\begin{array}{c}\text { Kelas } \\
\text { kata }\end{array}$ & $\begin{array}{c}\text { Frekuensi } \\
\text { (kali) }\end{array}$ \\
\hline 2 & 华小 & Sekolah jenis kebangsaan (Cina) (SJK(C)) & $\mathrm{KN}$ & 6,628 \\
3 & 独中 & Sekolah menengah persendirian Cina (SMPC) & $\mathrm{KN}$ & 3,615 \\
4 & 国民型中学 & Sekolah menengah jenis kebangsaan (SMJK) & $\mathrm{KN}$ & 729 \\
5 & 淡小 & Sekolah jenis kebangsaan (Tamil) (SJK(T)) & $\mathrm{KN}$ & 537 \\
6 & 国民型学校 & Sekolah jenis kebangsaan (SJK) & $\mathrm{KN}$ & 94 \\
7 & 国民型小学 & Sekolah jenis kebangsaan (SJK) & $\mathrm{KN}$ & 76 \\
8 & 国小化 & Menjadikan bercorak SK & $\mathrm{KK}$ & 33 \\
9 & 淡米尔小学 & SJK(T) & $\mathrm{KN}$ & 16 \\
10 & 淡米尔文小学 & SJK(T) & $\mathrm{KN}$ & 13 \\
11 & 英小 & $\begin{array}{l}\text { Disingkatkan daripada 英文小学, iaitu sekolah } \\
\text { aliran bahasa Inggeris }\end{array}$ & $\mathrm{KN}$ & 4 \\
\hline
\end{tabular}

Pengaruh asing khususnya peminjaman bahasa merupakan salah satu faktor penting evolusi bahasa (Aitchison 2001; Wang 2002). Perkataan "Tamil" dipinjam ke dalam BC China lalu menjadi 泰米尔 (Tamil), manakala kata nama ini dipinjam menjadi 焱米尔 (bahasa Tamil) dalam BC Malaysia. Peminjaman bahasa tersebut turut menghasilkan kata nama, iaitu 淡米尔小学 dan 淡米尔文小 学 dalam Item (9) dan (10) yang merujuk kepada SJK(T). Frasa nama pinjaman tersebut telah disingkatkan menjadi 淡小 (SJK(T)) dalam Item (5). Perbezaan dari segi cara peminjaman perkataan turut mengakibatkan 淡小 $(\mathrm{SJK}(\mathrm{T}))$ digunakan dalam KPM sahaja.

Penyingkatan kata merupakan salah satu ciri perkataan baharu dan berciri tempatan yang menjadikan item leksikal yang disingkatkan lebih singkat, padat dan mudah disebut (Chen dan Zhang 2011). 英文小学 disingkatkan menjadi 英小 dalam Item (11) untuk merujuk kepada sekolah rendah aliran BI. Sebaliknya, tiada penyingkatan sebegini dalam KPC dan BCC. Jelas di sini bahawa cara penyingkatan yang tersendiri juga merupakan faktor kewujudan perkataan berkaitan dengan pendidikan yang berciri tempatan. 
Yang menarik di sini, walaupun kata nama 国小 (SK) digunakan dalam ketiga-tiga korpus, tetapi 国小化 (menjadikan bercorak SK) dalam Item (8) yang berfungsi sebagai kata kerja hanya digunakan dalam KPM. Kata kerja ini menunjukkan bahawa SJK(C) dan SJK(T) di Malaysia telah dijadikan seperti SK, di mana kurikulum, cara pengajaran dan pembelajarannya menjadi semakin mirip dengan SK. Kata kerja ini digunakan dalam kalangan pengguna BC tempatan sejak tahun 2012. ${ }^{2}$ Fesyen merupakan salah satu faktor evolusi bahasa (Aitchison 2001) dan variasi bahasa. Menurut informan tempatan, hal ini disebabkan oleh pengguna $\mathrm{BC}$ tempatan terikut-ikut dengan fesyen dan trend masa kini, iaitu cenderung menambahkan morfem akhir 化 (-isasi) di belakang kata nama. Tambahan pula, terdapat empat jenis sekolah Malaysia yang diwujudkan di bawah konsep-konsep tertentu, seperti dalam Jadual 6 berikut.

Jadual 6: Sekolah tempatan yang diwujudkan di bawah konsep tertentu

\begin{tabular}{cllcc}
\hline Item & Perkataan & Terjemahan (BM) & Kelas kata & Frekuensi (kali) \\
\hline 12 & 宏愿学校 & Sekolah Wawasan & KN & 23 \\
13 & 精明学校 & Sekolah Bestari & KN & 14 \\
14 & 信托学校 & Sekolah Amanah & KN & 13 \\
15 & 控制中学 & Sekolah Kawalan & KN & 11 \\
16 & 控制学校 & Sekolah Kawalan & KN & 8 \\
\hline
\end{tabular}

Kata-kata nama dalam Item (12) hingga (16) dicipta untuk merujuk kepada sekolah-sekolah tempatan yang diwujudkan di bawah konsep tertentu. Antaranya 控制中学 adalah sama dengan 控制学校, iaitu merujuk kepada Sekolah Kawalan. Jelas di sini bahawa kata-kata nama tersebut dihasilkan khas untuk merujuk kepada sekolah yang hanya terdapat di Malaysia.

Terjemahan sama ada secara bunyi atau makna merupakan salah satu faktor kewujudan perkataan yang bervariasi dan berciri tempatan (Wang 2002; Cao 2010). Kata-kata nama tersebut adalah diterjemahkan daripada BM. Sebaliknya, tiada terjemahan sebegini dalam KPC dan BCC.

Kewujudan sekolah-sekolah tempatan tersebut turut menghasilkan pelbagai jenis kata nama $\mathrm{BC}$ yang merujuk kepada pelajar-pelajar yang belajar di sekolah-sekolah tersebut, seperti dalam Jadual 7.

Kata-kata nama dalam Item (17) hingga (22) merupakan item leksikal yang disingkatkan daripada frasa nama. Didapati bahawa frasa nama 国小学生 digunakan dalam KPC dan BCC untuk merujuk kepada pelajar SK, manakala kata nama yang lebih singkat, iaitu 国小生 (pelajar SK) digunakan dalam KPM sahaja untuk merujuk kepada pelajar tersebut. Faktor keringkasan merupakan salah satu faktor kewujudan item leksikal BC yang berciri tempatan (Huang 2014). Menurut informan tempatan, tujuan kata-kata nama yang singkat tersebut dihasilkan lalu 
digunakan dalam teks pendidikan adalah untuk menjadikan ayat teks tersebut lebih ringkas, pendek dan mudah dibaca.

Jadual 7: Pelajar sekolah berlainan di Malaysia

\begin{tabular}{cclcc}
\hline Item & Perkataan & Terjemahan (BM) & Kelas kata & Frekuensi (kali) \\
\hline 17 & 独中生 & Pelajar SMPC & KN & 317 \\
18 & 华小生 & Pelajar SJK(C) & KN & 157 \\
19 & 华校生 & Pelajar SJK(C) & KN & 37 \\
20 & 国小生 & Pelajar SK & KN & 12 \\
21 & 英校生 & Pelajar sekolah aliran Inggeris & KN & 6 \\
22 & 淡小生 & Pelajar SJK(T) & KN & 4 \\
\hline
\end{tabular}

Jadual 8: Pelajar berlainan etnik di Malaysia

\begin{tabular}{cclcc}
\hline Item & Perkataan & Terjemahan (BM) & Kelas kata & Frekuensi (kali) \\
\hline 23 & 华裔生 & Pelajar etnik Cina & KN & 106 \\
24 & 巫裔生 & Pelajar etnik Melayu & KN & 9 \\
25 & 印裔生 & Pelajar etnik India & KN & 13 \\
26 & 友族生 & Pelajar kaum lain & KN & 9 \\
27 & 异族生 & Pelajar kaum lain & KN & 6 \\
28 & 华族生 & Pelajar kaum Cina & KN & 6 \\
29 & 土著生 & Pelajar pribumi & KN & 5 \\
\hline
\end{tabular}

Keadaan masyarakat merupakan salah satu faktor luaran yang melahirkan perkataan-perkataan baru dan berciri tempatan (Wang 2002). Malaysia merupakan sebuah negara yang berbilang kaum, dan pelajar-pelajarnya terdiri daripada pelbagai etnik. Keadaan masyarakat ini turut melahirkan kata-kata nama yang merujuk kepada pelajar-pelajar yang berlainan etnik di Malaysia, seperti yang ditunjukkan dalam Item (23) hingga (29). Berdasarkan Jadual 8, Item (29) 土著生 ialah singkatan kata yang digunakan dalam KPM untuk merujuk kepada pelajar pribumi, manakala frasa nama yang lebih panjang, iaitu 土著学生 (pelajar pribumi) digunakan dalam KPC dan BCC untuk merujuk kepada pelajar tersebut. Jelas di sini bahawa cara penyingkatan kata yang tersendiri juga merupakan salah satu ciri perkataan berciri tempatan.

Kedua-dua kata nama, iaitu 巫裔 (etnik Melayu) dan 友族 (etnik lain) hanya digunakan di Malaysia, tetapi tidak digunakan di China. Faktor bahasa ini turut mengakibatkan item leksikal yang mengandungi kedua-dua kata nama tersebut, iaitu 巫裔生 (pelajar etnik Melayu) dan 友族生 (pelajar etnik lain) dalam Item (24) dan (26) tidak terdapat dalam KPC dan BCC. Tambahan pula, 友族生 dalam Item (26) merujuk kepada pelajar kaum lain yang dianggap sebagai sahabat 
oleh kaum Cina. Menurut informan tempatan, perkataan berciri tempatan tersebut dihasilkan untuk menunjukkan kemesraan dan persahabatan kaum Cina tempatan kepada etnik lain.

Selain itu, kata nama 留台生 (F: 21) digunakan dalam KPM sahaja untuk merujuk kepada pelajar negara lain (termasuk Malaysia) yang belajar di Taiwan. Menurut informan China, hubungan yang sensitif antara China dengan Taiwan turut mengakibatkan tidak ramai pelajar China melanjutkan pelajaran ke Taiwan. Faktor politik ini turut menyebabkan tiada perkataan yang digunakan untuk merujuk kepada pelajar tersebut dalam KPC dan BCC.

Pendidikan vokasional (技职教育) amat dipentingkan di Malaysia. Hal ini turut melahirkan kata nama 技职生 (F: 11) dalam KPM untuk merujuk kepada pelajar vokasional. Sebaliknya, frasa nama yang lebih panjang, iaitu 职业技术学 校学生 digunakan dalam KPC dan BCC untuk merujuk kepada pelajar jenis ini.

Selain kata-kata nama yang merujuk kepada pelajar, kata nama berciri tempatan juga digunakan untuk merujuk kepada pengajar, di mana 临教 (F: 957) dalam KPM adalah disingkatkan daripada 临时教师 yang merujuk kepada guru sandaran. Sebaliknya, tiada penyingkatan sebegini dalam KPC dan BCC. Menurut informan China, 教师 (guru) tidak disingkatkan menjadi 教 (singkatan bagi guru) dalam BC China kerana penyingkatan kata sebegini dianggap "luar biasa". Akan tetapi, informan tempatan menunjukkan bahawa singkatan tersebut menjadikan ayat dalam teks pendidikan tempatan lebih ringkas, pendek dan mudah dibaca.

Dalam KPM, terdapat tiga perkataan berciri tempatan yang berkenaan dengan aktiviti P\&P, seperti dalam Jadual 9 berikut.

Jadual 9: Aktiviti P\&P

\begin{tabular}{cclcc}
\hline Item & Perkataan & Terjemahan (BM) & Kelas kata & Frekuensi (kali) \\
\hline 30 & 教学营 & Kem pengajaran & KN & 13 \\
31 & 学习营 & Kem pembelajaran & KN & 7 \\
32 & 考试营 & Kem peperiksaan & KN & 4 \\
\hline
\end{tabular}

Sesetengah perkataan berciri tempatan adalah diterjemahkan daripada BM dan BI (Wang 2002). 教学营 (kem pengajaran), 学习营 (kem pembelajaran) dan 考试营 (kem peperiksaan) dalam Item (30) hingga (32) adalah terus diterjemahkan daripada frasa nama BM, dan ketiga-tiga kata nama tersebut hanya digunakan dalam KPM. Sebaliknya, frasa nama yang lebih panjang, iaitu 教学培训, 学习培训 dan 考试培训 digunakan dalam KPC dan BCC untuk merujuk kepada ketiga-tiga kem latihan tersebut. Hal ini turut menunjukkan bahawa penterjemahan daripada BM juga merupakan faktor kewujudan perkataan berciri tempatan. 
Jadual 10: Kata nama yang berkaitan dengan perguruan

\begin{tabular}{cllcc}
\hline Item & Perkataan & Terjemahan (BM) & $\begin{array}{c}\text { Kelas } \\
\text { kata }\end{array}$ & $\begin{array}{c}\text { Frekuensi } \\
\text { (kali) }\end{array}$ \\
\hline 33 & 师训学院 & Maktab perguruan/Institut pendidikan guru (IPG) & KN & 124 \\
34 & 师资荒 & Masalah kekurangan tenaga pengajar & $\mathrm{KN}$ & 52 \\
35 & 师荒 & Masalah kekurangan tenaga pengajar & $\mathrm{KN}$ & 6 \\
\hline
\end{tabular}

Berdasarkan Jadual 10, 师训学院 (maktab perguruan/IPG) dalam Item (33) digunakan dalam KPM sahaja untuk merujuk kepada maktab perguruan dan IPG. Sebaliknya, 师范学院 (IPG) digunakan dalam ketiga-tiga korpus untuk merujuk kepada maktab perguruan, kolej perguruan atau IPG.

Sekolah-sekolah jenis kebangsaan di Malaysia, khususnya SJK(C) menghadapi masalah kekurangan tenaga pengajar yang serius selama ini. ${ }^{3} \mathrm{Hal}$ ini turut melahirkan dua kata nama, iaitu 师荒 dan 师资荒 (masalah kekurangan tenaga pengajar) dalam Item (34) dan (35) untuk merujuk kepada masalah tersebut. Berdasarkan Jadual 10, Item (35) 师荒 adalah singkatan daripada 师资荒 dalam Item (34). Sebaliknya, 教师荒 digunakan dalam BCC untuk merujuk kepada masalah kekurangan pengajar, khususnya di Taiwan dan negara England.

Jadual 11: Kelas di sekolah tempatan

\begin{tabular}{cclcc}
\hline Item & Perkataan & Terjemahan (BM) & $\begin{array}{c}\text { Kelas } \\
\text { kata }\end{array}$ & $\begin{array}{c}\text { Frekuensi } \\
\text { (kali) }\end{array}$ \\
\hline 36 & 母语班 & Kelas bahasa ibunda (POL) & KN & 71 \\
37 & 董事班 & $\begin{array}{l}\text { Kelas yang khas untuk pelajar yang } \\
\text { direkomen oleh pengelola sekolah }\end{array}$ & $\mathrm{KN}$ & 9 \\
38 & 单轨班 & Kelas “landasan tunggal” & $\mathrm{KN}$ & 4 \\
39 & 双轨班 & Kelas “landasan berkembar” & $\mathrm{KN}$ & 3 \\
\hline
\end{tabular}

Dari segi kelas pula, 母语班 (kelas bahasa ibunda (POL)) dalam Item (36) hanya wujud dalam KPM untuk merujuk kepada kelas BC atau bahasa Tamil (BT) yang dibuka di sesetengah SMK di Malaysia, di mana kelas ini dijadualkan pada waktu sebelum atau selepas persekolahan. Kelas ini dinamakan 母语班 (kelas bahasa ibunda) kerana BC dan BT merupakan bahasa ibunda kepada pelajar Cina dan India di sekolah tersebut. Sebaliknya, menurut informan China, tiada konsep dan kelas sebegini di China disebabkan BC merupakan mata pelajaran bahasa yang wajib dipelajari oleh semua pelajar sekolah pada waktu persekolahan di China.

Berdasarkan Jadual 11, sejenis lagi kelas diwujudkan di sekolah di Malaysia, iaitu 董事班 dalam Item (37) yang disingkatkan daripada 董事推荐班 (kelas yang pelajarnya direkomen oleh pengelola sekolah). Sebaliknya, menurut 
informan China, tiada kelas khas sebegini di China disebabkan sekolah kerajaan di negara tersebut biasanya tidak mempunyai lembaga pengelola sekolah. Jelas di sini bahawa organisasi sekolah yang berbeza juga merupakan salah satu faktor kemunculan perkataan berkaitan dengan pendidikan yang berciri tempatan.

Selain itu, 单轨班 (kelas "landasan tunggal") dalam Item (38) merujuk kepada kelas SMPC yang pelajarnya hanya mempelajari mata pelajaran peperiksaan bersepadu UEC, manakala 双轨班 (kelas "landasan berkembar") dalam Item (39) merujuk kepada kelas SMPC yang pelajarnya perlu mempelajari mata pelajaran peperiksaan bersepadu UEC dan juga peperiksaan awam. Oleh sebab tiada perkataan yang berkenaan dalam perbendaharaan kata $\mathrm{BC}$ standard, maka kedua-dua item leksikal tersebut dicipta lalu digunakan oleh pengguna $\mathrm{BC}$ tempatan untuk merujuk kepada kedua-dua jenis kelas SMPC yang hanya terdapat di Malaysia. Seperti yang dinyatakan oleh Aitchison (2001) dan Wang (2002), perkataan-perkataan berciri tempatan dihasilkan kerana ia diperlukan untuk merujuk kepada sesuatu yang hanya terdapat di kawasan atau negara tertentu.

Tambahan pula, terdapat juga kata-kata nama berciri tempatan yang digunakan untuk merujuk kepada sistem pendidikan di Malaysia, seperti dalam Jadual 12 berikut.

Jadual 12: Sistem pendidikan di Malaysia

\begin{tabular}{cclcc}
\hline Item & Perkataan & Terjemahan (BM) & $\begin{array}{c}\text { Kelas } \\
\text { kata }\end{array}$ & $\begin{array}{c}\text { Frekuensi } \\
\text { (kali) }\end{array}$ \\
\hline 40 & 固打制 & $\begin{array}{l}\text { Sistem kuota kemasukan pelajar ke institusi } \\
\text { pengajian tinggi awam (IPTA) }\end{array}$ & KN & 65 \\
41 & Sistem langkau kelas & KN & 5 \\
\hline
\end{tabular}

Oleh sebab 固打制 (sistem kuota) dalam Item (40) digunakan dalam KPM untuk merujuk kepada sistem kuota kemasukan pelajar ke IPTA, maka ia dikategorikan sebagai perkataan yang berkaitan dengan pendidikan. 固打 (kuota) dalam item leksikal tersebut merupakan kata pinjaman dari BI dan BM, iaitu quota dan kuota. Sebaliknya, tiada peminjaman bahasa sebegini dalam BC China. Perkataan yang digunakan dalam KPC dan BCC untuk merujuk kepada sistem kuota ialah 配额制 dan 限额制 (sistem kuota).

Kata nama 跳班制 dalam Item (41) merujuk kepada sistem langkau kelas yang membolehkan pelajar darjah tiga terus memasuki darjah lima, atau darjah enam terus ke tingkatan satu tanpa melalui peringkat kelas peralihan. Walaupun kata kerja 跳班 (langkau kelas) terdapat dalam ketiga-tiga korpus, tetapi kata nama 跳班制 (sistem langkau kelas) hanya dipakai dalam KPM, manakala 跳级 制 digunakan dalam KPC dan BCC untuk merujuk kepada sistem yang sama. 
Di Malaysia, terdapat persatuan-persatuan yang sentiasa mempertahankan dan mengambil berat terhadap perkembangan pendidikan BC tempatan. Sebaliknya, tiada persatuan-persatuan pendidikan sebegini di China. Hal ini turut mengakibatkan perkataan-perkataan yang merujuk kepada persatuan-persatuan pendidikan tersebut hanya wujud dalam KPM, seperti dalam Jadual 13.

Jadual 13: Persatuan pendidikan di Malaysia

\begin{tabular}{cclcc}
\hline Item & Perkataan & Terjemahan (BM) & $\begin{array}{c}\text { Kelas } \\
\text { kata }\end{array}$ & $\begin{array}{c}\text { Frekuensi } \\
\text { (kali) }\end{array}$ \\
\hline 42 & 董总 & $\begin{array}{l}\text { Persekutuan Persatuan-persatuan Lembaga } \\
\text { Pengurus Sekolah Cina Malaysia, iaitu Dong } \\
\text { Zong }\end{array}$ & KN & 2603 \\
43 & 教总 & $\begin{array}{l}\text { Persekutuan Persatuan-persatuan Guru Sekolah } \\
\text { Cina Malaysia, iaitu Jiao Zong }\end{array}$ & KN & 986 \\
44 & 董教总 & $\begin{array}{l}\text { Persekutuan Persatuan-persatuan Lembaga } \\
\text { Pengurus dan Guru Sekolah Cina Malaysia, } \\
\text { iaitu Dong Jiao Zong }\end{array}$ & KN & 423 \\
45 & 家协 & $\begin{array}{l}\text { Persatuan Ibu Bapa dan Guru (PIBG) } \\
\text { Lembaga pengelola sekolah, persatuan ibu bapa } \\
\text { dan guru }\end{array}$ & KN & 336 \\
47 & 董家教 & Kesatuan Perkhidmatan Perguruan Kebangsaan \\
(KPPK) & KN & 163 \\
教专 4 & $\begin{array}{l}\text { Persatuan Jaringan Ibu Bapa Pencinta Pendidikan } \\
\text { BC }\end{array}$ & KN & 6 \\
\hline
\end{tabular}

董总 (Dong Zong) dan 教总 (Jiao Zong) dalam Item (42) dan (43) merupakan dua persekutuan persatuan yang mempertahankan pendidikan BC di Malaysia, di mana kedua-dua kata nama tersebut telah melalui proses penyingkatan. Kombinasi kedua-dua kata nama tersebut melahirkan satu lagi kata nama yang berciri tempatan, iaitu 董教总 (Dong Jiao Zong) dalam Item (44).

Berdasarkan Jadual 13, terdapat juga persatuan-persatuan yang melibatkan pengelola sekolah, ibu bapa dan guru di sekolah Malaysia. 家协 (PIBG) dalam Item (45) adalah disingkatkan daripada 家教协会 (PIBG). Walaupun 家教协会 juga wujud di China (dalam BCC), tetapi item leksikal tersebut bukan merujuk kepada PIBG, sebaliknya merujuk kepada 家庭教育协会 (persatuan pendidikan keluarga) dan 家庭教师协会 (persatuan tutor rumah). Item leksikal dalam BCC tersebut tidak disingkatkan menjadi 家协 (PIBG) seperti dalam KPM.

家总 dalam Item (48) disingkatkan daripada 华文教育家长总会, iaitu Persatuan Jaringan Ibu Bapa Pencinta Pendidikan Bahasa Zhonghua (BC). Persatuan tersebut membolehkan ibu bapa yang mengambil berat tentang pendidikan $\mathrm{BC}$ membincangkan isu-isu pendidikan $\mathrm{BC}$ tempatan serta bersama- 
sama menyelesaikan masalah yang berkaitan dengan pendidikan BC. Sebaliknya, $\mathrm{BC}$ dijadikan sebagai bahasa utama dan bahasa yang wajib dipelajari oleh semua pelajar di China. Justeru, persatuan tersebut tidak diperlukan di China.

Selain itu, terdapat tiga kata nama yang merujuk kepada hari peringatan, alat pengangkutan, dan majlis hanya digunakan dalam KPM (lihat Jadual 14).

Jadual 14: Perkara-perkara lain yang berkaitan dengan pendidikan

\begin{tabular}{cclcc}
\hline Item & Perkataan & Terjemahan (BM) & Kelas kata & Frekuensi (kali) \\
\hline 49 & 华教节 & Hari pendidikan BC & KN & 16 \\
50 & 学巴 & Bas sekolah & KN & 9 \\
51 & 开课礼 & Majlis pembukaan sekolah & KN & 6 \\
\hline
\end{tabular}

Perkataan baharu bukan sahaja dicipta untuk merujuk kepada sesuatu benda, konsep, sistem dan teknologi yang baru (Chen dan Zhang 2011), tetapi juga merujuk kepada sesuatu yang hanya terdapat di tempat yang tertentu. Disebabkan oleh keperluan sosial seperti yang dinyatakan oleh Aitchison (2001), kata nama 华教节 (hari pendidikan BC) dalam Item (49) dicipta lalu digunakan dalam KPM untuk merujuk kepada perayaan yang berkaitan dengan pendidikan $\mathrm{BC}$ tempatan. Perayaan ini diadakan pada setiap hujung tahun. Aktiviti-aktiviti yang diadakan sempena perayaan ini bertujuan untuk mengenang jasa dan sumbangan tokoh yang banyak berkorban demi mempertahankan pendidikan BC di Malaysia, iaitu Lim Lian Geok. ${ }^{5}$

Didapati bahawa 校巴 digunakan dalam ketiga-tiga korpus untuk merujuk kepada bas sekolah, manakala 学巴 (bas sekolah) dalam Item (50) hanya digunakan dalam KPM. Kata nama tersebut disingkatkan daripada 学校巴士, 学校大巴 (bas sekolah) atau 学生巴士 (bas pelajar). Menurut informan China, biasanya 学校 (sekolah) dan 学生 (pelajar) tidak dipendekkan menjadi morfem 学 (sekolah atau pelajar) dalam BC China. Faktor pemendekan kata turut mengakibatkan kata nama tersebut ditemui dalam KPM sahaja.

Meskipun 开课 dan 开学 mempunyai hubungan makna sinonim, iaitu samasama merujuk kepada buka sekolah, namun 开课礼 dalam Item (51) digunakan dalam KPM untuk merujuk kepada majlis pembukaan sekolah, manakala 开学礼 dipakai dalam KPC dan BCC untuk merujuk kepada majlis yang sama.

\section{KESIMPULAN DAN IMPLIKASI}

Sebanyak 69 perkataan berkaitan dengan pendidikan yang berciri tempatan dikesan. Hampir semuanya, iaitu 68 perkataan $(98.55 \%)$ daripadanya merupakan kata nama, dan hanya satu (1.45\%) kata kerja dikesan. Sebahagian besar daripada 
perkataan tersebut digunakan untuk merujuk kepada orang yang terlibat dalam pendidikan, sekolah dan institusi pengajian, benda-benda yang berkaitan dengan P\&P serta persatuan pendidikan tempatan. Sebaliknya, hanya sebahagian kecil daripada perkataan tersebut digunakan untuk merujuk kepada jenis, pentadbiran, dan sistem pendidikan.

Konsep, polisi, sistem, keadaan, dan organisasi pendidikan di Malaysia yang berlainan dengan China turut mewujudkan kata-kata nama yang berciri tempatan. Kepelbagaian sekolah, kelas, dan etnik di Malaysia juga menghasilkan pelbagai jenis kata nama berciri tempatan yang merujuk kepada sekolah, kelas, dan pelajar. Sesetengah benda dan perayaan yang berkaitan dengan pendidikan hanya terdapat di Malaysia, sebaliknya tiada di China. Justeru, kata-kata nama BC yang berciri tempatan telahpun dihasilkan untuk merujuk kepadanya.

Hasil analisis menunjukkan bahawa penyingkatan kata merupakan salah satu ciri perkataan berkaitan dengan pendidikan yang berciri tempatan dalam KPM. Perkataan tersebut disingkatkan daripada frasa. Sebaliknya, tiada penyingkatan kata sebegini dalam BC di China. Didapati bahawa penterjemahan terus daripada BM juga merupakan salah satu faktornya.

Tambahan pula, keperluan sosial dalam kalangan masyarakat Cina tempatan turut melahirkan pelbagai jenis kata nama berciri tempatan yang merujuk kepada sekolah, kelas, persatuan pendidikan dan juga perayaan yang berkaitan dengan pendidikan BC. Terdapat juga perkataan berciri tempatan dihasilkan untuk menunjukkan persahabatan dan kemesraan kepada etnik lain di Malaysia. Wang (2002) menyatakan bahawa pengaruh dialek Cina juga merupakan salah satu faktor yang melahirkan item-item leksikal yang berciri tempatan. Namun, hasil analisis kajian ini menunjukkan bahawa tiada sebarang perkataan BC berkaitan dengan pendidikan yang berciri tempatan dihasilkan akibat pengaruh dialek Cina.

Hasil analisis menunjukkan bahawa semua perkataan berkaitan dengan pendidikan yang berciri tempatan tersebut masih belum dimasukkan ke dalam kamus-kamus BC seperti Kamus Ensiklopedia Pendidikan dan Kamus BC Moden. Hanya sebahagian kecil daripadanya, iaitu 16 (23.19\%) perkataan telah dimasukkan ke dalam Kamus BC Global Abad Baru (2010).

Dapatan kajian korpus bukan sahaja membantu dalam P\&P bahasa, tetapi juga memberi sumbangan kepada perkamusan (Yang 2012; Abdul Rahman et al. 2014). Pelbagai jenis perkataan berkaitan dengan pendidikan yang berciri tempatan telah dikenal pasti melalui penyelidikan ini. Memandangkan sebahagian besar daripada perkataan berciri tempatan yang dibincangkan di atas digunakan sebanyak lima kali dan lebih dalam KPM, maka ahli-ahli leksikografi BC dicadangkan untuk mempertimbangkan agar memasukkan perkataan-perkataan tersebut ke dalam kamus BC moden dan kamus BC global yang akan diterbitkan pada masa hadapan. Hal ini bukan sahaja dapat memperkaya perbendaharaan kata dalam kamus BC, malahan menjadikan kamus tersebut lebih terkini dan sesuai 
dengan perkembangan semasa. Situasi ini juga membolehkan golongan pembaca memahami makna item-item leksikal berciri tempatan tersebut melalui kamuskamus BC. Tujuannya adalah untuk membolehkan golongan pembaca mencapai tahap pemahaman yang sama dengan penulis di samping mengelakkan salah tafsir makna oleh pembaca. Sesetengah perkataan yang berciri tempatan juga boleh dimasukkan ke dalam teks-teks yang membincangkan isu-isu pendidikan dalam buku teks BC sekolah rendah dan sekolah menengah di Malaysia agar bersesuaian dengan perkembangan zaman dan kehendak kurikulum semasa.

\section{NOTA}

1. Laman webnya ialah http://bcc.blcu.edu.cn/.

2. Selepas berita di atas talian disemak melalui Google, didapati bahawa kata kerja ini tidak digunakan dalam akhbar-akhbar BC di Malaysia sebelum tahun 2012.

3. Sumber: http://www.sinchew.com.my/node/879444

4. Disingkatkan daripada 全国教师专业职工会, iaitu kesatuan perkhidmatan perguruan kebangsaan.

5. Sumber: https://llgcultural.com

\section{RUJUKAN}

Abdul Rahman Mohammed, Said Ahmed, Mowaffaq Mohammed and Mansour H. Wahby. 2014. Promoting awareness of teaching collocations techniques to beginners (adjective-noun collocations). http://eujournal.org/index.php/esj/article/ viewFile/3147/3017 (accessed 16 January 2015).

Aitchison, J. 2001. Language change: Progress or decay? 3rd ed. Cambridge: Cambridge University Press.

Anderson, W.J. 2006. The phraseology of administrative French: A corpus-based study. Amsterdam-New York: The Netherlands.

Cao, F.X. 2010. Cong dangdai xin ciyu shiyong kan yuyan bianyi. People's Tribune 29(1), June. http://paper.people.com.cn/rmlt/html/2010-10/11/content_661041.htm (accessed 18 July 2017).

Chen, J.M. 1999. Zhongguo yuyan he Zhongguo shehui. Guangzhou: Guangdong Jiaoyu Chubanshe.

Chen, M.F. dan P. L. Zhang. 2011. Social development and Chinese new words. Science Economy Society 122(29): 80-84.

Chen, Y. 1998. Chenyuan yuyanxue lunzhu. Shenyang: Liaoning Jiaoyu Chubanshe.

Chong, S.L. 2007. Cong Malaixiya huawen baozhang shiyong de ciyu ji qi xingshi tan Malaixiya fengqing. In Discovering the language - Diversity, variation and standardization, eds. S.L. Chong and S. Chiah, 103-124. Kuala Lumpur: Penerbitan Seni Hijau Sdn. Bhd. 
Hickey, R. 2012. Internally and externally motivated language change. In The handbook of historical sociolinguistics, eds. J.M. Hernández-Compoy dan J.C. Conde-Silvestre, 401-421. Malden, MA: Wiley-Blackwell. https://doi. org/10.1002/9781118257227.ch21

Hishamudin Isam and Norsimah Mat Awal. 2011. Analisis berasaskan korpus dalam menstruktur semula kedudukan makna teras leksikal setia. GEMA Online ${ }^{\text {TM }}$ Journal of Language Studies 11(1): 143-158.

Huang, H.Y. 2014. Malaixiya Huayu ciyu yanjiu. PhD diss., Department of Chinese Language and Culture, Southwest University.

Labov, W. 2001. Principles of linguistic change, volume 2: Social factors. Oxford: Blackwell.

Lau, S.K. 2010. Malaixiya Zhongwen guanggao jingci shiyong. Chinese Sociolinguistics 15(1): 119-129.

Leech, G. 2002. The importance of reference corpora. http://www.uzei.eus/wp-content/ uploads/2017/06/06-Geoffrey-LEECH.pdf (accessed 28 January 2018).

Li, Y.D. 1998. Xiandai Hanyu ciyu dapei. Beijing: Shangwu Yinshuguan Guoji Youxian Gongsi.

Li, Y.M. 2010. New century global Chinese dictionary. Beijing: The Commercial Press.

Loh, P.P. 2009. Leksis baru bahasa Cina dalam bidang ekonomi. Master's diss. Faculty of Languages and Linguistics, University of Malaya.

McEnery, T., R. Xiao and Y. Tono. 2006. Corpus-based language studies: An advanced resource book. London and New York: Routledge Taylor and Francis Group.

Peng, Z.L. 2012. Peixun gengduo shizi - Longshi shifanxueyuan ying fuban Huawen zu. Sin Chew Daily, 6 April. http://news.sinchew.com.my/node/242654 (accessed 20 August 2016).

Seng, L.C. 2006. Penciptaan istilah-istilah baru bahasa Cina dan penggunaannya dalam surat khabar dan majalah. Master's diss. Faculty of Languages and Linguistics, University of Malaya.

Shi, D.X., J.M. Shao and Z.Y. Zhu. 2006. Gangshi Zhongwen yu biaozhun Zhongwen de bijiao. Hong Kong: Hong Kong Educational Publishing Company.

Siti Aeisha Joharry and Hajar Abdul Rahim. 2014. Corpus research in Malaysia: A bibliographic analysis. Kajian Malaysia 32(1): 17-43.

Song, Z.R. dan X.P. Yang. 2006. Hanyu xin ci xin yu nianbian. Chengdu: Bashu Shushe.

Tan, K.C. 2008. Analisis perkataan bahasa Cina dalam bidang hiburan dan sukan. Master's diss. Faculty of Languages and Linguistics, University of Malaya.

Tang, Z.X. 2004. Lun Huayu quyu teyou ciyu. http:/www.huayuqiao.org/articles/ tangzhixiang/tang08.pdf (accessed 17 June 2017).

Trask, R.L. 1994. Language change. London; New York: Routledge.

Wang, H.D. 2002. Xinjiapo Huayu teyou ciyu tanwei. In Xinjiapo Huayu cihui yu yufa, eds. Q.H. Zhou, 25-74. Singapore: Lingzi Media Pte Ltd.

Yang, T.Y. 2012. Guanyu biancuan xiandai Hanyu changyong shici dapei cidian de shexiang. 202.206.100.3/xi/wxy/goxiang.doc (accessed 24 December 2016). 